\title{
Deconstructing the Past in Indonesian Contemporary Dance
}

\author{
Wahyu Novianto \\ Theater Department, Indonesia Institute of the Arts Surakarta, Indonesia \\ Dwiyasmono \\ Dance Department, Indonesia Institute of the Arts Surakarta, Indonesia \\ Taufik Murtono \\ Visual Communications Design Department, Indonesia Institute of the Arts Surakarta, Indonesia
}

\begin{abstract}
Contemporary dance in Indonesia was in the encounter between traditional dance and modern dance. Traditional dance in Indonesia could be seen from two forms, namely traditional dance that grew and developed inside the palace walls (classical dance) and traditional dance that grew and developed outside the palace walls (folk dance), while modern dance was a dance that had shown its contact with Western world. Traditional dance was a form of collective expression, while modern dance was a personal expression. It was in this context that Indonesian contemporary dance found its form. Contemporary dance in Indonesia always tried to re-dialogue the forms of dance that had been there before, both traditional and modern to be brought back with a new spirit and values in accordance with the current conditions of society. Deconstruction became a way to re-read dance worked that already exist, to be communicated again with the community today.
\end{abstract}

Keywords: contemporary dance, deconstruction, tradition, modern.

DOI: $10.7176 / \mathrm{ADS} / 78-02$

Publication date: November 30th 2019

\section{Introduction}

Performing arts that lived and developed in a society could not be separated from the structure of that society. The structure of society was what had formed a universe with their respective interests and peculiarities. Communities that were bound together with common needs, and paid considerable attention to the universe with all of its contents, both in the form of a 'visible' and 'invisible' universe, and a group that always tried to provide a balance of both by carrying out various religious activities is the community who lived in the rural area. While people who were no longer bound by shared solidarity, or even solidarity with the universe and its environment, and felt indifferent to something 'invisible' around them, slowly had begun to shift from the soil cultivation system to a machine management system industry, was an urban community.

The two universes namely rural and urban communities had different interests. So the forms of performance art that they produced were also different. The form of performance art that had been produced was a cultural expression of each universe. Dance performances organized by rural communities were a collective act, whereas in urban communities it had become an individual act. As a collective act, dance performances were bound by a system of values, norms, and rules that had been believed and agreed upon together. Meanwhile, as an individual act, dance performances were free and were separated from various bonds or rules that surrounded them. In this position the form of dance in rural communities was referred to as traditional dance, and for urban people the dance was referred to as modern dance.

Our traditional dances were dances that were created inside the walls of the palace (classical dance) and outside the walls of the palace (folk dance). The dance that was born inside the walls of the palace was created by feudal people who had a very clear hierarchy, and the highest authority was in the hands of the king. The king was the embodiment of a deity or bearer of the powers of ancestral spirits. In Brahmanism's view, the king was considered as a living god, a human being in whom was a Hindu god, usually Shiva or Vishnu who incarnates (Brandon, 2003: 22). Then his shoulders supported the safety and welfare of the whole community. Therefore, the form of dance created must imply respect and devotion to the king. Full of symbols, sacred, moral teachings, and great values that must be obeyed - not to be questioned (Kayam, 1985: 142). Examples were visible in the wayang wong performance and langendriyan.

Different situations were occurred in dance that was created and developed outside the palace walls. The function of dance in this environment was not as a binder of solidarity between the people and their king, but between society and nature and the environment that surrounded it. Dance was closer to various religious ceremonies, offerings to the spirits of the ancestors who inhabited the village. Dance activities carried out by the surrounding community were encouraged by - Koentjaraningrat called it - a religious emotion. A feeling that there was a mighty power that was beyond human reach. It was this religious emotion that encouraged people to carry out various religious activities, communicated and sought relationships with that mighty power. This made 
it seem as if the community felt safe, comfortable, and protected by that power. In the modern view, the actions taken by the people outside the palace walls were like a form of life insurance.

This noble, neat, formal, and complicated form of classical dance was a logical consequence of the vision of feudal society, as well as folk dance forms that looked more spontaneous and simple. The vision of the people inside and outside the walls of the palace, not only differed in the discussion it conveyed (the content), but also how to convey it (the form). Dance from inside the palace wall was called 'fine' art, while dance created outside the palace was called 'rough' dance. 'Fine' dances and 'rough' dances could carry out their own dance concepts while they were in their respective environments.

This dichotomy between 'fine' and 'rough' did not apply in modern dance. Modern dance was dance created by urban communities. A universe that was no longer bounded by shared solidarity. This society had become an individual society, so the form of dance presented was no longer reflecting on collective expression but individual expression. Humans were seen as a whole entity with all the problems it was faced. The social problems presented on the stage, with the characters who were 'ordinary' people, were no longer super heroes who were protected by the power of gods or ancestral spirits.

\section{Deconstructing the Past to Create the Present}

The past and the present were an expanse of human culture. Between the past and the present there was a connection between the inheritors and the heirs. This was the key to tradition, tradition was the totality of objects and ideas that came from the past, but actually still existed today, had not been destroyed, damaged, discarded, or forgotten. Tradition means inheritance, what is really left from the past (Sztompka, 2005: 70). The view was inn line with Shils, that tradition means everything that is distributed or passed down from the past to the present (1981: 12). What was inherited could be in the form of objects (artifacts) and ideas (thoughts). It seemed that traditional dance had inherited both the object (artifacts) and the idea behind the object (the content).

The shape of an object and its contents was aesthetic unity, it was built and could only be interpreted or could only communicate with the universe in which it was located. In this case, dance would certainly continue to organize and to change itself so that it could communicate with the universe. This view then gave rise to contemporary dances. Contemporary dance was based on the spirit of art to actualize tradition in order to be contextual with the present. The form of self-actualization could be done with various variants, according to the place, time, and condition of the artwork when it was produced. Finally, contemporary dance became a dance that routinely explored both shapes and ideas into 'new' shapes and ideas, but consciously could still be traced to its original cultural roots.

This aspect of 'novelty' in contemporary dance seemed to had led some artists to the opinion that contemporary must be something unique, or even strange, something that was not yet presented in any cultural universe. This understanding made the artists composed their work by distorting the form in such a way that it became a new packaging and form, though the new essence in contemporary dance was a new perspective in reading or seeing the past to answer current problems. Contemporary was an artistic attitude that was authentic and was born from a personal insight that was not bound by any limitation. Contemporary artists were born from an ever-changing condition, an opened universe with various values and choices, and in that world artists were free to choose and make choices.

Putu Wijaya firmly said that all performances that contained meaning, mission, breakthrough, or just an experiment, to free themselves from the confines of time, place, situation; obsolete values, corpses of spiritual wandering that were no longer relevant - were contemporary works (1994: 2). Contemporary works freed themselves from a single form of meaning. They freed themselves from congestion on a value that was originally thought to be the source of everything, while everything turned out to had shifted and turned everything upside down. What was conveyed in contemporary dance were alternative values, shadow values, concepts that were reconstructed for consideration, to disturb the mind, to be contemplated, to shake belief, for anything other than to be 'kept in mind', 'lived in', and 'carried out' (Kayam, 1985: 144).

The freedom of expression carried by Indonesian contemporary dance also seemed to have upset some traditional artists. Some traditional artists in Indonesia insisted that tradition could not be messed up. Tradition must be sterilized from anything that could damage the tradition itself. Some traditional artists in Indonesia considered that contemporary dance was a distortion of the symbolic and mystical nature because basically traditional dance was noble. This caused the decline in the quality and value of traditional arts. While other artists argued that it was time for tradition to be read and reproduced again with a new spirit in accordance with the times. The term 'noble' in traditional art did not have a clear terminology. By some artists, the term is actually considered to have fostered fanaticism and sentimentality in artistic life and can mask creativity (Lindsay, 1991: 76).

As long as the tradition remained sterilized from anything else, the tradition was getting farther and farther from its universe. It had been finished and could not be read again in line with the changing times. So it took creative attitudes to make that tradition could still be read according to the context of the times. The creative 
attitude taken was not merely by displaying various traditional dance idioms into contemporary forms, because that would only produce artificial forms. But far from that, it was creating a dialogical correlation between past and present, in order to bring back ancient values in the modern context. In this way it was hoped that the various symbols and metaphors contained in traditional art could be read again by subsequent generations. In this context, the sustainability of Indonesian dance continues.

\section{Deconstructing the Past}

Creative attitude of a director, who was always critical in seeing the reality (tradition) he encountered, was the beginning in creating a new reality. This new reality was a reality of imagination that only appeared in the head of the artists, as a result of the response to the reality they faced. The reality of imagination was the ideal reality that should occur, a vision, ideals, and goals to be achieved by the artists. Through their works, artists were struggling to present their visions. It may be that their vision was different from the reality they faced because they reformed existing reality, even rearranged it, so as to create new realities that provided alternatives, possibilities, and other perspectives in seeing and living the reality they encountered.

Thus the practice carried out by the artists was a practice of deconstruction. This deconstruction, translated as 'dismantling', provided a perspective to not always believe in texts. A text was always correlated and had a context, so that it always contained the possibility of other meanings. This deconstruction perspective was originally conceived by Jacques Derrida, an Algerian-born philosopher who later settled and died in France. This deconstruction came as a reaction to the failure of modernism under the structuralism thinking. Deconstruction became the main characteristic of post-structural idea.

Deconstruction as a method for dismantling a text rejected the stability or the establishment of a text. The text must be read in a completely new way regardless of the creator of the text. Deconstruction separated traditional concepts between the creator and his work. Deconstruction had actually killed the author, turned history and tradition into inter-textual and elevated the reader (Sarup, 2008: 77). Affirmed by Grenz (2001: 236), that deconstruction overturned classical dualism and ruined the existing system. This view had made the text continue to develop. There was no interpretation that could claim itself as the final interpretation. The text would change shape in the hands of the readers. This was the era of readers' life, having previously been dominated by authors.

In this view deconstruction provided a great opportunity for the creation of contemporary dance. Realities of the past that existed both in the tradition and modern universe in Indonesia must be read, dismantled, and questioned again, until new realities that had been hidden from the dominant interpretations of past reality were finally found. Deconstruction was also able to bring up other meanings of a text whose meanings were previously dominated by the dominant version. This new reality and other meanings were also likely to be read, dismantled, and questioned again by other readers, so as to produce new realities and other meanings, and so on, to the point of being unlimited. As a result, new realities and other meanings of past realities would be held lively on the stages of Indonesian contemporary dance performances.

\section{Conclusion}

Because dance was still seen as a communication event, then to present the cultural expression of the past for the present universe, there was no other way except only by doing deconstruction. Remodeled the structure, installation, and order of existing values, then traced back the context of the dismantled past, to look for epistemological patterns, thus raising creative questions to be formulated in creating a new structure, installation, and order of values. This was actually the meaning of creators. Armed with creativity, they must be able to create new realities and meanings from existing realities that had been believed to be true.

Indonesian contemporary dance was a form of dance deconstruction that had existed before. Indonesian choreographers such as Sardono W. Kusumo, Miroto, Eko Supriyanto, etc., always read texts from the past. They deconstructed the past texts to be brought back to the present. Sardono diligently interpreted Balinese texts such as the story of Calon Arang which was deconstructed into a "Dongeng dari Dirah" performance. Miroto, as a maestro of Javanese classical dance in Yogyakarta, did a lot of exploration of Javanese classical dance movements, as well as Eko Supriyano who was familiar with Javanese folk dance. Folks dances motions adorned each of his works. For them dance was no longer seen as a series of beautiful movements, but dance had become a mobility of the body. Motion would go back and forth between the realistic and symbolic, between the denotative and connotative.

\section{References}

Brandon, James. R. 2003. Theatre in Southeast Asia. Penerjemah: Prof. Dr. R.M. Soedarsono. Bandung: P4ST UPI.

Gernz, Stenky J. 2001. A Prmer On Postmodernism. Penterjemah: Wilson Suwanto, Yogyakarta: Yayasan Andi. Kayam, Umar. 1985. "Nilai-Nilai Tradisi, dan Tari Kontemporer Kita" dalam Menengok Tradisi: Sebuah 
Alternatif Bagi Tari Modern. Penyunting: Tuti Indra malaon, Afrizal Malna, dan Bambang Dwi. Jakarta: Dewan Kesenian Jakarta.

Lindsay, Jennifer. 1991. Klasik, Kitsch or Contemporary: A Study of the Javanese Performing Arts. Penerjemah: Nin Bakdi Sumanto. Yogyakarta: Gadjah Mada University Press.

Sarup, Madan. 1993. An Introductory Guide to Post-Structuralism and Postmodernism. Penerjemah: Medhy Aginta Hidayat. Yogyakarta: Jalasutra.

Sztompka, Piotr. 2005. Sosiologi Perubahan Sosial. Jakarta: Prenada.

Wijaya, Putu. 1994, "Kontemporer", dalam Jurnal SENI edisi IV/01 - Januari 2994, Yogyakarta: BP ISI Yogyakarta. 